\title{
Pension Reforms and Risk Sharing Cycle: A Theory and Global Experience
}

\author{
Ishay Wolf ${ }^{1}$, Lorena Caridad y Lopez Del Rio ${ }^{2}$
}

\begin{abstract}
:
Purpose: This paper offers an explanation to pension systems cyclical reforms, based on Central East Europe (CEE) countries experience over the last three decades.

Design/Methodology/Approach: This paper develops a theory of risk sharing process and demonstrate it based on global experience over the last two decades.

Finding: During the transition to funded pension design, the government not only transfers longevity and fiscal risks to the individual but also absorbs risks transferred from the public, where each market actor transfers undiversifiable risks to the other. The outcomes of this risk path realized in financial transfers, such as social security, means-tested and minimum pension guarantee. Consequently, funded pension designs naturally converge to a new landscape paradigm of risk sharing, including intergenerational and intra-generational play. Financial crises such as the recent COVID-19 pandemic foster the convergence process.

Practical Implications Governments and central planners have to consider risk sharing mechanisms to ensure sustainability of pension designs during the transitions to funded schemes.

Originality/Value: To the best of the author's knowledge, no other paper attempted to study the bi-path ways of risk during the pension transition and discover the mutual expectation of the pension market actors. There is a vast literature of risk sharing study in comparison between funded and unfunded pension schemes.
\end{abstract}

JEl: G18: H55: H75: J38

Keywords: Social security, pension, risk, minimum pension guarantee, political pressure, adequacy, pension reform.

Research Type: Research paper.

${ }^{1}$ Ph.D., Cordoba University in Spain, Ishay.wolf1@gmail.com;

${ }^{2}$ Ph.D., Cordoba University in Spain 


\section{Introduction}

Since the 1990s, countries around the globe have introduced pension structural reforms, moving from the public pay-as-you-go (PAYG) defined benefit (DB) model to individual accounts in a multipolar architecture (Ebbinghaus 2015). The main reason was and still is fiscal constriction as of low fertility and longer periods at retirement. In an aging Europe, governments could not oblige anymore to adequate pension level in PAYG DB schemes without raising taxes (Holzmann and Hinz, 2008). This entailed diverting funds from the public pension system into individually funded accounts. (From a financial perspective, through the transition of pension design, the government financial position changes at the pension system's transition, as it cancels its obligation on a specific replacement level. The government buys options on the former replacement level particular level.)

However, in many countries, these reforms were short-lived. At the onset of the global economic crisis, most countries that had adopted pension privatization reforms either halted them, drastically reduced the private element or completely abandoned them (Arza, 2012; Naczyk and Domonkos, 2016; Orenstein, 2013; Sokhey, 2017). The financial market crash in 2008 has challenged the merits of privately funded pensions as their assets experienced a substantial decline within a short time (Grech, 2018; Altiparmakov, 2018). Consequently, over the last decades, the trust in the new pension pillar system's sustainability has been shattered (Ebbinghaus, 2015).

In practice, pension privatization did not deliver the expected results. Coverage rates decreased, pension benefits deteriorated, and gender and income inequality increased, making reforms unpopular (Guardiancich, 2017; Grech, 2018). The increased role of supplementary pension funds and the recent economic and financial downturn have led to new challenges about future financial sustainability and pension benefits' adequacy. Now it is clear that the direction of pension reforms appears to have changed again, with many countries reversing the policies they adopted in the 1980s and 1990s (Arza, 2008; Ebbinghaus, 2015; Mesa Lago and Valero, 2020; Barr and Diamond, 2016; Thalassinos et al., 2019; Cristea and Thalassinos, 2016).

The literature on risk-sharing in pension schemes has started to emerge with the privatization wave and the continuous debate on the balance pension design. Some papers are more analytical and examine the efficient allocation of the funded pension fund and the individual savings (Goiller, 2008), and some papers focus on the government role and adequate benefits level (Natali, 2009; Hinrich, 2015; Oliviera and Ponomarenko, 2017). This strand of literature claims that the growing role of defined contribution (DC) funded pensions may leave individuals exposed to a wide variety of risks, threaten consumption in old age. The common individual cannot manage these risks by themselves. The late examples for that are the financial crisis in 2008 and the COVID-19 pandemic crisis, in which governments have been obligated to provide enormous rescue and social plans to their citizens. Nobody ever expected the individual to manage these buckets of risk alone within their personal 
pension account. In most cases, the average individual is not even aware of those risks (Randle and Rudolph, 2014).

Another strand of literature has examined the pension systems processes across Eastern Europe and Latin-America, as countries in these regions started to roll back from a DC pension scheme to a PYAG DB pension scheme with an unstable landscape. Many of them present various reasons for the reversals-political, fiscal stress, and more (Natali, 2018; Altiparmakov, 2018; Zandberg and Spierdijk, 2013).

This composition contributes to these two strands of literature by pointing to a bipathways flow of risks among the government and the public while shifting to a more funded pension scheme. We ask if funded pension schemes entail a risk path from the public to the government in addition to the familiar shifting of risks from the government to the individual. We claim that the mutual expectations of risk-sharing among the public and the government will eventually determine an equilibrium of pension pillar sizes, where each actor tries to shift to the other undiversifiable risks. In fact, we link the above-mentioned reasons for reversals in CEE and Latin American countries to a lack of risk-sharing mechanisms between the government and the public. The gap results in political pressure and eventually cyclical pension reforms.

We further argue that economic shocks, such as the financial crisis in 2008 and lately the COVID-19 pandemic crisis, may foster this process, as the risks were realized faster. After developing the theory of risk-sharing expectations between the government and the individual, we demonstrate this theory on CEE countries countries' pension reversals experience in the second part of this paper.

In the next section, we describe the mutual risk-sharing model in funded pension funds. In Section 3, we detail the opportunities of risk-sharing from the individual to the government. We define government intervention levels in the market as risksharing "Orders." We argue that the probability of another pension reform depends on these orders' efficiency. We review different risks, financial, personal, and structural risks that are being diversified through risk-sharing orders. Section 4 demonstrates the implementation of risk-sharing orders in pension systems reversals across CEE countries as part of the converge process toward equilibrium among actors in the field. Section 5 discusses the linkage between the risk-sharing theory to CEE countries' pension experience. Section 6 provides conclusions.

\section{The Cycle Scheme}

During pension transition to a more funded, capitalized one, the government transfers undiversified fiscal risks to individuals. This fiscal risk translates to various risks on the individual's pension portfolio and triggers a risk-sharing cycle. 


\subsection{The Government's Expectations}

The main difference between DB and DC schemes comes from the exposure to different types of risks and how these risks are allocated between employer, employee, plan sponsor, and the government (Rappaport and Peterson, 2014). Any change in the pension system affects the risk-sharing framework and bears a balance of risk ensemble among actors.

In pension schemes, the government is considered a mediator actor among different participants' generations and different field actors (Tausch et al., 2013). However, since the government has another public spending every year $(\mathrm{G})$ and fiscal constraints, it desires to lower pension spending and minimize its risks. Transition to a funded pension scheme enables the government to lower the first pillar size (social security) and redirect taxes to finance other public needs (Espin-Andersen, 1990).

\subsection{The Individual's Expectations}

The individual expects to retain his standard of living in old age in any pension scheme and avoid poverty (Kuitto and Kuivalainen, 2020). From the individual perspective, the fiscal risk transition translated to a bucket of risk for families, such as longevity risk, market risk, solvency risk, asymmetric information risk, career risk, and systemic risk. Some of the risks have been transferred directly from the government, such as longevity risk and some system changes, such as market risk. From the individual's point of view, the risk source is not important but his ability to diversify it. In the analog to the capital asset pricing model (Markowitz, 2010), the individual expects a risk premium for the risks he cannot diversify. The market risks are the most intuitive example. The individual benefits from the opportunity to gain from the market exposure over the former pension scheme (Goiller, 2008). However, what is the risk premium to exposure to longevity risk or to asymmetric information risk?

Based on global experience, as will be discussed in the second part, we argue that risk premium expectations evolve to political pressure and pension reversals or structural changes (Altiparmakov, 2018). If a system is not seen as beneficial by the electoral majority, namely, if it does not help them maintain their pre-retirement living standards, it could be voted out (Bradley et al., 2016; Grech, 2018). After this process, the risk premium can address many forms, including increasing the social security financial transfers, imposing minimum pension guarantee, and even government obligation to an adequate benefit level (Mabbett, 2020; Altiparmakov, 2018; Mesa Lago, and Valero, 2020).

The benchmark for the individual benefit expectation is not clear. We assume that the former PAYG DB benefit level is only a theoretical reference point. The expectations depend on a personal and general variety of variables, such as risk appetite and the peer group pension benefits at retirement. Political pressure can arise due to 
disappointing form pension benefits, or if the performances are relative to the previous generations or compare to previous market conditions (for example, the streets demonstrations in Greece in 2012, in Lebanon in 2019, and France in 2019).

\subsection{Pension Market in Equilibrium.}

Summing up the balance of interests in the pension market:

- The individual expects a risk premium in addition to the expected benefit from the funded fund scheme. The individual uses political pressure to increase the risk premium to a satisfactory level.

- The government wishes to decrease its financial obligations and its future fiscal risks.

Figure 1 demonstrates the balance mechanism toward an equilibrium of pension benefit. From one side, the government transfers fiscal risk and changes the pension system to a funded capitalized one. In the same line, the government tries to cut fiscal transfers to the individual. On the other side, the public expects a risk premium on the excess of risks they could not diversify or transfer on their behalf. This risksharing process converged to an equilibrium of benefits and risks.

Figure 1: Individual Expectation of Pension Benefit

Benefit After the Transition

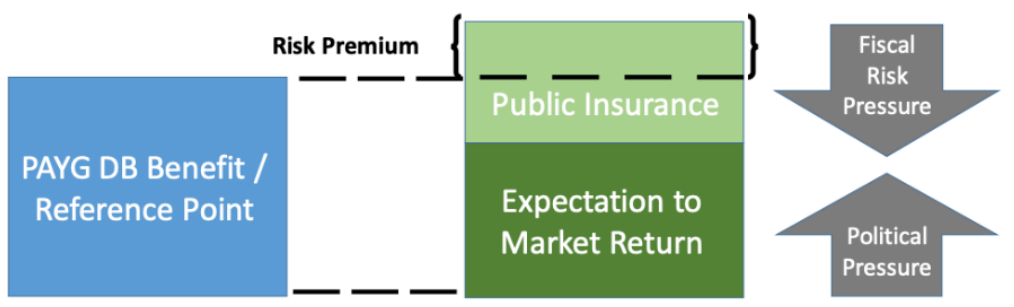

Source: Own creation.

These expectations are not equal among the public cohort. The importance of diversification is most significant for low and middle earning cohorts. While highearning cohorts usually have other sources of assets and savings apart from the pension scheme, low and middle earning cohorts are leaning heavily on old-age pension benefits (Tausch et al., 2013). Additionally, low earning cohorts have fewer resources to diversify risks. These cohorts are vulnerable and will be stuck in recession situations when the systematic risk may be realized. Market returns' compensations are not high enough to cover economic theoretical loss from periods without significant contributions during the career phase.

Here, we claim that the income inequality level in the market affects the pension equilibrium above. Since the government transfers the individual's risks, the opposite 
risk-sharing depends on the actor's strength. As more individuals are in a close financial situation, the individual becomes stronger against the government, and the probability of a pension reversal increases.

\section{Risk-Management Processes}

In this subsection, we overview the risk-sharing mechanism in which each side transfers undiversifiable risks to the other party. Pension plan designs range from those that place virtually all of the plan's risk, such as traditional PAYG DB design, to those that place nearly all the risk on the individual covered by the plan DC scheme. Neither is ideal (Rappaport and Peterson, 2015), and no model is superior (Barr, 2006). We refer to three government intervention levels in the market, or 'orders.' These orders can be considered an opposite pathway of risks from the individual back to the government.

\subsection{The 1st Order: Pension Risk Sharing by Market Design}

Countries choosing to base their pension systems on private funds must first have well-established financial markets, as well as adequate public and government understanding and mutual trust (Bohn, 2010). From one side, the government transfers fiscal risk and longevity risk to the public and changes the pension system (Leisering, 2003).

On the other side, the government is obligated for operations in market design, enabling efficient capitalized pension accumulations in personal portfolios. Regulation and governance enable diversifying market failures (Grech, 2018). The individual cannot manage inherent market failures/risks and transfer those to the government responsibility. We overview the main pension risks that are managed and shared by a healthy market design:

\section{A. Longevity Risk}

When shifting from the DB scheme, the government transfers longevity risk to the public (Longevity risk can be further addressed from time to time by automatic benefits' adjustments or by periodically raising retirement ages.). The outcome is sensitivity to low fertility and average life expansion in higher contributions and lower old-age benefits. Regulation and market design enable risk-pooling in the annuities market (in other words, by buying annuities, individuals absorb the longevity risk as a group with the same age cohort) (Reichling and Smetters 2015).

An annuity creates a redistribution ex-post, as some individuals die early and forfeit their resources to those who die later. In that form, through plan sponsors, individuals can manage idiosyncratic mortality risk; additionally, by enabling the annuity market, the individual shares this risk with his same age cohort. 


\section{B. Asymmetric Information}

This market failure risk includes insufficient regulatory and transparency, fiduciary risk, undeveloped financial infrastructure, or imperfect information regarding the labor market and the insurance companies. Many individuals do not have the motivation, knowledge, or skill to provide a satisfactory retirement income independently. Many DC participants will not have adequate retirement benefits because contributions are too little, or they have used the money too early or have not earned enough investment income due to overly conservative or poorly timed decisions. Member individuals did not manage these kinds of risks before pension reforms and needed advisory and trust in the central planner (Bohn, 2010).

Naturally, the pension system's transition depends on sustainable market infrastructure, which can enable the individual to pool these risks with others and make rational decisions (Leisering, 2003). Clearly, these two risk families are supposed to be managed at the macro level by government agencies and regulators, as the individual is too small to influence the system (Einav et al., 2010; Adams et al., 2010). Figure 2 describes the risk spectrum as a function of government/individual risk-bearing. The red color signifies high risk-bearing, whereas the green color indicates the possibility for diversification of risk to the respective actor. The yellow color indicated risk-bearing on some level. Respectively, when the pension design moves from the pure DC scheme with actively central planner market design, the individual's risk-bearing change to yellow instead of red.

Figure 2. Risk Sharing by Market Design

\begin{tabular}{|l|l|c|c|c|c|}
\hline \multicolumn{7}{|c|}{ Panel A: Risk Sharing by Market Design } \\
$\begin{array}{c}\text { Actor / } \\
\text { Government } \\
\text { Intervention Scale }\end{array}$ & Pure Funded DC & $\begin{array}{c}\text { 1st Order: Market } \\
\text { Design and } \\
\text { Regulation }\end{array}$ & $\begin{array}{c}\text { 2nd Order: } \\
\text { Mix Scheme }\end{array}$ & $\begin{array}{c}\text { 3rd Order: } \\
\text { Mix Scheme + } \\
\text { Minimum Pension } \\
\text { Guarantee }\end{array}$ & DB PAYG \\
\hline Government & Low & Low & Low & High \\
\hline Individual & High & \multicolumn{3}{|c|}{ Risk Pooling } & Low \\
\hline
\end{tabular}

Source: Own creation.

\section{Facial Risk}

As was revealed in the financial crisis in 2008 and again during the COVID-19 pandemic global crisis, in times of recession, the government needs fast and available financial resources. In a systemic global crisis, this money tends to be expensive, as risk premiums soar, and the government is forced to raise money in the open market with higher interest rates (Bielawska, 2015). Eventually, the public would have to bear the interest rate costs. A loan from savings from pension funds wealth is a win- 
win solution among the government and the public. These monetary resources could have been invested in national infrastructure projects to wake economies with high returns and government agencies' close supervision. Instead, in times of macroeconomic shocks, it might absorb drastic drops in the financial markets.

A mixed pension scheme with a substantial public scheme can be a fiscal instrument for the government in raising capital to foster economic activity during recessions and ease weaker cohorts' consumption without weakening its long-term viability (Barr and Diamond, 2009). Consequently, from the government's perspective, our color model is a pure DC scheme; some may argue that the color should be yellow and not green.

\subsection{The 2nd and the 3rd Orders: Intergenerational and Intra-generational Risk- Sharing}

If the individual can manage their pension account in an efficient market and the first order is valid, we manage accumulations risks and their working phase. We define the second order as the implementation of social security and the third order as public social transfers, such as means-tested programs and minimum pension guarantee implementation. These mechanisms are socio-economic transfers from the government to the individual. The government tries to minimize fiscal risk by transitioning to the funded-privatized pension scheme in the first place (Holzmann et al., 2008). Hence, the government hedges social security fiscal risk by intergenerational risk-sharing (Hardy, 2020). The diversification of social security mechanism is held by redistribution among adjacent generations as part of the unfunded PAYG feature. The third order augments and intensifies the second order's risk diversification effect. This order includes implementation of target pension, means-tested or minimum pension guarantee. The third order involves a mix of intergenerational and intra-generational risk-sharing mechanisms. Learning from global experience, governments worldwide with funded schemes make efforts to impose automatic modifications of these mechanisms (Natali, 2018).

The government income redistribution mechanism diversifies mainly financial risks and wage/carrier risks, which cannot be managed in the individual's portfolio by themselves (Mabbett, 2020). These kinds of risks are, naturally, much more critical for weak cohorts, as they do not have enough resources to diversify or manage realizations of these risks.

As part of the third order, imposing a minimum pension guarantee deepens diversification of personal and financial risks, which can be realized due to wrong decisions along the individual's career path, economic shocks, or systemic risk. Meaning, it may provide a safety cushion in times of recession when a strong correlation between wage reduction and unemployment is realized with capital market fall (Antolin et al., 2011). 


\section{Market Risk}

Unfunded pillar and/or minimum pension guarantee is uncorrelated to capital markets and is a cushion against market falls. Many countries operate rate of return minimum pension guarantee in funded pension schemes for that reason (Marx, 2016; OECD, 2019). In times of financial crisis, such as in 2008 and the COVID-19 pandemic crisis, which includes realizations of correlations between risks-financial, personal, or systemic risk, we witnessed a significant rise in the government transfers.

\section{E. Solvency Risk}

Workers in occupational pension schemes receive their current and future income from the same source, and therefore are highly dependent on their employer, suffering a 'double blow' if they enter bankruptcy. Portfolio theory argues that efficient risk bearing requires sufficient diversification across asset classes and individual issuers. However, it may be difficult for employees to diversify the risk posed by their current and future income coming from a single source (Zaidi, 2010).

As pointed in Figure 3, in government DB plans, we assume there is no risk to the individual, as the government credit risk is higher, by definition than any insurance company. HOWEVER, in DC plans, individual participants bear most of the solvency risk if the financial institution or particular investment funds become insolvent. As government intervention deepens and a larger fraction of benefits depends on public benefits, solvency risk reduces.

\section{F. Wage / Career Risks}

Wage/career risks in a family are correlated to the individual's choices and fortune and their career and at the end of their working phase. Due to the accrued effect in funded pension schemes, the continuity of working is highly significant to adequate pension benefits. Government social transfers, which are not correlated completely to the individual's wage path, might diversify this kind of risk on some level, as providing an economic cushion for old age. In that case, the government participates in that risk up to some level.

\section{G. Labor Market Distortions}

Social security and minimum pension guarantee may alleviate labor distortions risk. One can consider the employer's contributions to social security/pension guarantee due to the differed wage ensured by governmental deposit. Hence, the justification for governmental pension benefit schemes is providing a layer of security for beneficiaries against a sponsor's bankruptcy and therefore compensates for any asymmetric information and correct any market failure (Tausch et al., 2013). They can be seen as credit cushions where the individual cannot assess their employer bankruptcy risk. In that case, the employer contributions are, in fact, 'differed wage.' 
Figure 3 points to a 'mirror' risk-sharing position between the individual and the government. As studied above, the government's fiscal spending diversifies the above risks in some levels. Practically, the government as a mediator participates in riskbearing through social security and minimum pension guarantee instruments. These orders' effectiveness is higher with low correlations between government transfers and wages (Grande and Visco, 2010). That is essential in realizing tail risk and for the weak earning cohorts who have not enough wealth and knowledge to diversify that risk with their own portfolios.

Figure 3. Panel B. Classic Bidirectional Risk Flow

\begin{tabular}{|l|l|l|l|l|l|}
\hline $\begin{array}{c}\text { Actor I } \\
\text { Government } \\
\text { Intervention Scale }\end{array}$ & Pure Funded DC & $\begin{array}{c}\text { 1st Order: Market } \\
\text { Design and } \\
\text { Regulation }\end{array}$ & $\begin{array}{c}\text { 2nd Order: } \\
\text { Mix Scheme }\end{array}$ & $\begin{array}{c}\text { 3rd Order: } \\
\text { Mix Scheme + } \\
\text { Minimum Pension } \\
\text { Guarantee }\end{array}$ & DB PAYG \\
\hline Government & Low & & & & High \\
\hline Individual & High & & & & Low \\
\hline
\end{tabular}

Source: Own creation.

The minimum pension guarantee is unique by its risk-sharing effect. The state budget can be financed (intergenerational risk-sharing) or with differentiation on the first pillar benefits allocation (intergenerational + intragenerational risk-sharing). This means retirees cannot receive higher benefits than the contributions collected and fair value accumulation (Grande and Visco, 2010). However, this is all true to the sumup level. The intergenerational diversification between young and old and intragenerational diversification entails that there is not always a direct bond between contributions and benefits.

\section{The Experience of Convergence toward Pension Design Equilibrium}

\subsection{Why CEE Countries?}

In this section, we demonstrate the converging process to risk-sharing equilibrium in funded pension schemes. Many pension reforms were designed and driven by the World Bank, based on the argument of the impending crisis of aging and its impact on pension systems' sustainability (e.g., World Bank, 1994). At the same time, Western European countries with matured public pay-as-you-go systems have dismissed pension privatization initiatives. Most profound and extensive pension reforms took place in the 1990s in Latin America and Eastern Europe (Bielawska, 2015).

Between 1981 and 2018, 29 countries undertook pension reforms, introducing partial privatization or full privatization with individual accounts and private administrations (Altiparmakov, 2018). However, 19 countries, 13 in Eastern Europe and 6 in Latin 
America, reversed privatization, $60 \%$ of the countries that had privatized pension reversed privatization. Five other Latin American countries have strengthened the zero pillar of minimum pension guarantee (Mesa Lago and Valero, 2020).

Here, we focus on CEE countries reversals from a risk-sharing orders perspective. While every country case is specific and needs to be assessed in its context, the implementation of risk-sharing mechanisms has common elements in the new pension systems' configuration during pensions the re-reforms wave. Specifically, the literature finds common characteristics in the following CEE countries history of cyclical pension reforms: Russia, Latvia, Estonia, Bulgaria, Croatia, Latvia, Lithuania, Kazakhstan, North Macedonia, Poland, Hungary, Czechia, Romania, Slovakia, and Slovenia.

Empirical evidence shows that these reforms failed to deliver the improvements initially propagated by the World Bank (1994). Coverage rates stagnated or decreased, pension benefits deteriorated, and gender and income inequality increased (Fultz and Hirose, 2019). The financial crisis severely affected financial and capital markets, significantly reducing the real value of private pension assets and, consequently, causing popular outrage with the private system's results. The risk of financial market fluctuations was left to pensioners.

Many pensioners had to rely on social support as the value of their pension benefits had fallen to deficient levels, often below the poverty line (a study by the InterAmerican Development Bank (IADB)) highlighted the decline in replacement rates in a pure funded DC scheme- the Chilean Model from 1990 to 2000 when half the private system participants received a declining minimum pension (Crabbe, 2015). Drop-in replacement rates were also in Argentina. Further, Cichon (2004) concluded that average pension amounts were likely to gravitate toward the minimum levels). Moreover, administrative costs further reduced pension benefits, and workers' participation in management was eliminated (Ebbinghaus, 2015). In section 3, we explain that in a lack of risk-distributions mechanisms. Consequently, political risks push decision takers to reverse back to PAYG schemes.

However, when compared to CEE country's reforms to funded pension designs, most Western high-earning countries in Europe still implement the dominant first pillar in the form of the DB PAYG pension scheme (see Figure 4). According to the OECD annual report (OECD, 2019), most pension reforms in advanced countries can be summed in parametric changes, such as consistently raising the retirement age and adapting contribution rated with no drastic reforms or reversals. The relatively stable pension landscape in advanced countries is due to a balance between financial needs and the system's generosity (Fultz and Hirose, 2019). Through liberal markets, competitive and sophisticated financial private sector, and high government regulation come to realize. These inherent mechanisms may diversify asymmetric information, market distortions, and provide available and efficient instruments hedging financial risks through capital markets (Zaidi, 2010). 
Figure 4. Dominant pension schemes across Europe ${ }^{3}$

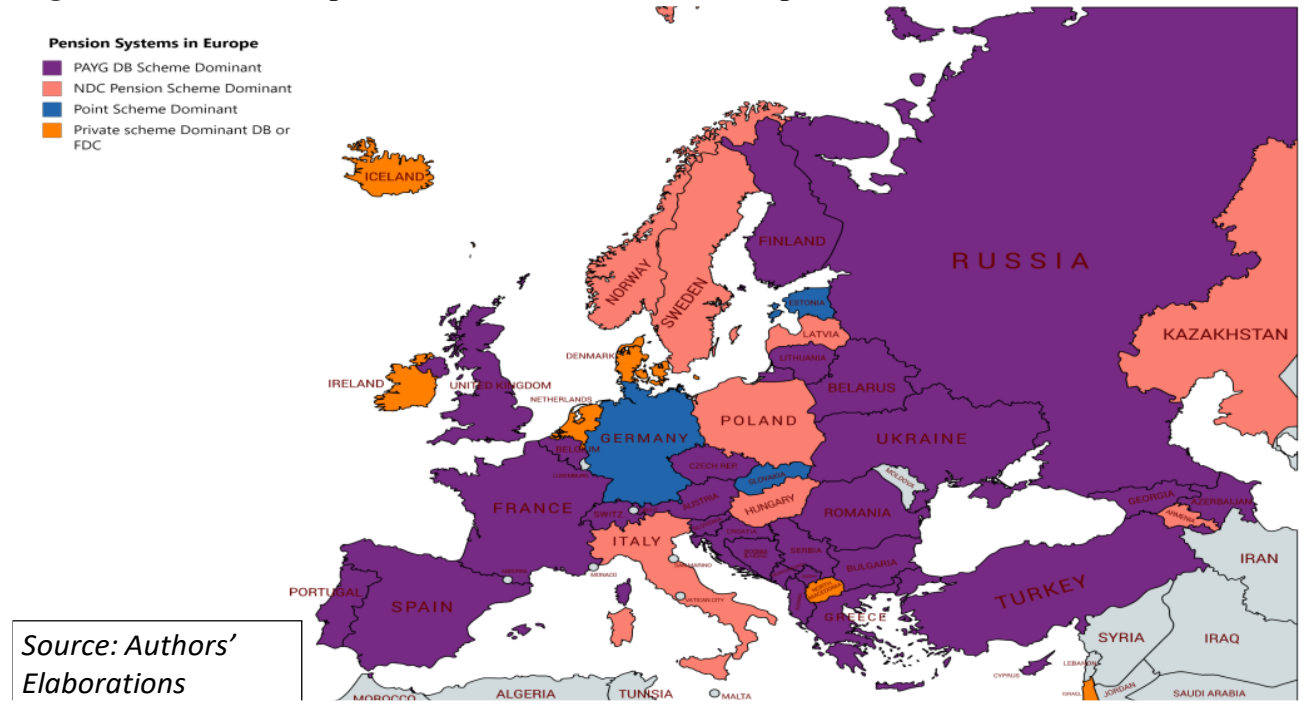

Source: Own creation.

\subsection{Lack of the $1^{\text {st }}$ Risk-Sharing Order}

CEE countries in the 1990s were out of the communist regime, and capital markets were still lacking supervision and mutual trust. Guardiancich (2010) claims that in Poland, private fund supervision went through continuous organizational changes and took almost ten years to develop but remained riddled with inefficiency and excessive politicization. Inadequate consulting and marketing practices, early withdrawal penalties, and low tax incentives, as well as crowding out by the first pillar, prevented voluntary pensions from expanding. Undeveloped markets cause inefficient investments and high volatility and risk for participants (Munnell and Quinby, 2009).

We show how pension reversals substantially improve the market design, regulation, and governance. Over the years, government intervention created trust among actors after the soviet regime with more transparency and efficiency in the private funds' operations.

Many European governments maintained a 'voluntarist approach' to organizing private welfare provisions until the 1990s. This implies that the allocation of occupational and personal welfare benefits was left to 'private initiative' (EspingAndersen, 1990). Lack of governance in designing pension reforms was realized when many CEE governments (Croatia, Estonia, Latvia, North Macedonia, Poland, and Slovakia) launched their 2nd pillar before they defined its benefits package that workers could expect to receive (Fultz and Hirose, 2019).

\footnotetext{
${ }^{3}$ Most of the countries across Europe have hybrid or mix pension schemes. We choose to mark the dominant pension schemes in these countries.
} 
A centralized public administration has replaced the major design problems in most of the privatization reforms. Governments improve adequate policy formulation and related decision-making processes. The re-reforms reinforced the government's role in the administration, regulation, and supervision of the pension systems. After rereforms, such as Poland, Hungary, and Kazakhstan, most countries created autonomous bodies for the regulation and supervision of private pensions (MesaLago and Valero, 2020).

The experience in CEE countries also revealed the problem in the budget risk transfer. According to the evidence, the reforms during the 1990s failed to improve fiscal and financing terms and financing the transition toward individual accounts exacerbated pre-existing fiscal pressure in most countries (Altiparmalov, 2018). The mix of pillars eases fiscal stress for enough time to foster economic activity and to socially ease low earning cohorts during a deep recession and decreasing overall debt. Governments were able to invest part of the nationalized funds in public development projects (e.g., nuclear power electricity plants, roads, trains, public housing, etc.). The target was to create positive multiplier effects about public revenues, such as taxes and social security contributions (Hujo and Rulli, 2014).

\subsection{Lack of the 2nd and the 3rd Risk-Sharing Orders}

An interesting indicator of healthy intergenerational risk sharing in pension is the poverty rate transition from the old to the young. Between the mid-1990s until the end of 2016, most European countries improved the poverty rate in old age about the entire population across Europe (Figure 5). Here, across some of the CEE countries, however, the trend is the exact opposite, as old-age poverty has increased. That may indicate insufficient risk-sharing mechanisms inherent in pension systems and one reason for political pressure to conduct re-reforms. A large variety of improvement rates in old-age poverty in the sample countries stem from the timing and the intensive rate of imposing pension privatization reforms and reversals. For example, the improvement of the relative old-age poverty rate in Slovenia may be attributed to abolishing the 2nd pillar as part of the re-reforms. Moreover, Slovakia improved to impose the late partial privatization-capitalization pillar with a small 2 nd pillar, which has operated for only three years until the reversal. In both of the cases, the 3rd order might have played an important role.

In Figure 6, we point to a convergence process of implementing minimum pension guarantee or target pension after pension reform reversals. In red color, we have the CEE countries that have been through pension reform during the 1990s and made reversal. These countries are compared to Western countries in Europe, colored in yellow, which implement target or minimum pension guarantee. In the appendix, we overview the main reversal of CEE countries according to the definitions of the risk sharing orders. All analysed countries have been re-balancing their radical reforms since the 1990 s and early 2000 s by implementing $2^{\text {nd }}$ and the $3^{\text {rd }}$ risk-sharing orders and recognizing public social insurance. 
Figure 5. Poverty shift in Europe: Aged over 65 vs. 18-25.

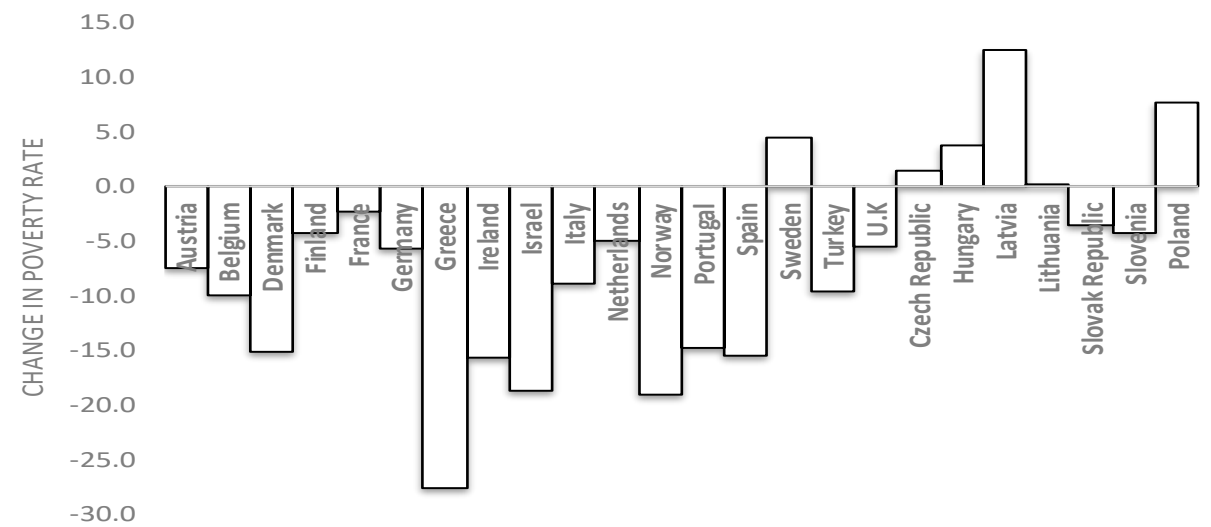

Source: Based on OECD/ Pension at Glance, 2019

Furthermore, they redesigned social security based on the principles of social solidarity, redistribution, and shared responsibility for pension provision among actors (Fultz and Hirose 2019; Marchal et al., 2014). Pension systems' re-balancing was done by various methods:

- Increasing $1^{\text {st }}$ pillar contributions in the expense of the $2^{\text {nd }}$ pillar-Poland, Bulgaria, Latvia, Lithuania, Czechia.

- Providing individuals the option to reverse back to the $1^{\text {st }}$ pillar of public pension and social security from the $2^{\text {nd }}$ pillar (private funded funds) - Bulgaria, Croatia, Hungary and Slovakia.

- Imposing minimum pension guarantees and intergenerational diversificationsHungary, Poland, Czechia, Slovakia, Latvia, Slovenia and Kazakhstan.

Figure 6. Implementation of minimum pension guarantee in Europe

minimum pension after reversal
minimum pension or target pension

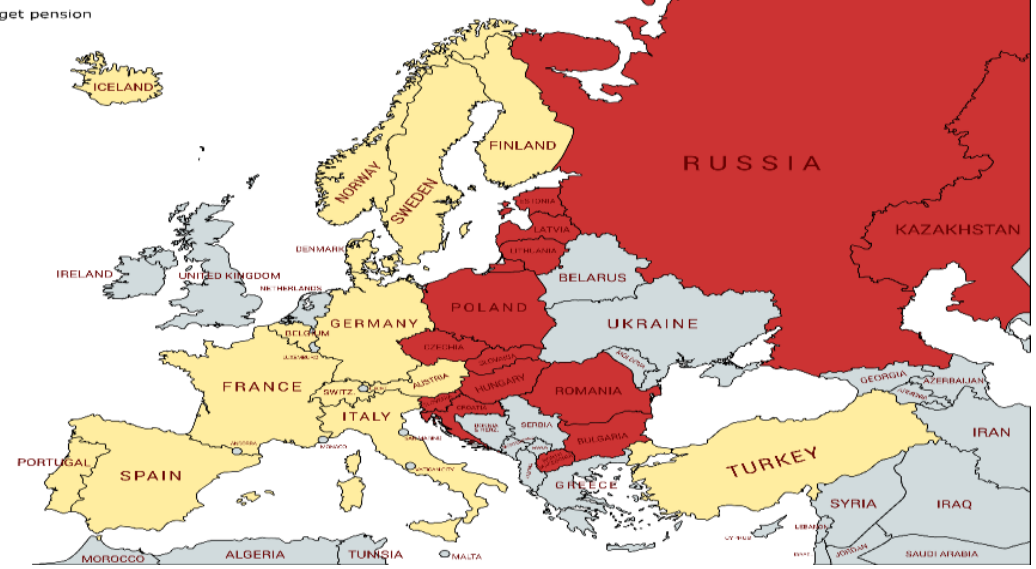

Source: Own creation. 


\section{Discussion}

There is little doubt that successfully 'averting the old-age crisis' in Eastern Europe will need to involve private pension funds. However, their funding, operations, and interactions with other public pension pillars will need to resemble successful practices in developed countries instead of relying on the radical World Bank (1994) reform blueprint.

The comparison between Western countries and CEE countries demonstrates that when the pension market is pre-mature and unregulated, the public seeks other financial risk mechanisms. That may lead to political pressure focus on governmental transfers, such as increasing social security and imposing minimum pension guarantees. This process explains the deviation in market designs among the different countries, which choose funded-capitalized pension schemes, dealing with the same challenges of low fertility, longevity, and fiscal risks.

Nowadays, we still identify continuing reversal process even a decade after the financial crisis, such as in Romania (2018) and Croatia (2019), including the learning process, which is reflected in the comprehensive pension design risk-sharing mechanisms to improve and sustain their pension systems.

Given the political economy of reforms, the large voting power of people nearing or beyond retirement age might mount again to recalibrate public pensions and regulate private pensions (Munnell and Quinby, 2009). Indeed, the literature recognizes that imposing a minimum pension guarantee is an important condition to any transition to a more funded-capitalized scheme to assure sustainability of pension schemes and make them politically acceptable (Marx, 2016). Almost all actual reform proposals have guaranteed current law scheduled benefits (Antolin et al., 2011). Pension guarantee is becoming more and more required in volatile markets.

According to the above, it is not surprising to notice a global shifting trend in implementing minimum pension guarantee mechanisms (Lachance et al., 2003; Arza, 2008). Guarantees in DC schemes have recently become more common, especially in Latin America, which has been at the forefront of pension privatizations (MesaLago and Valero, 2020). Those countries join stable pension economies across Europe, which implement minimum pension guarantees, such as Finland, Germany, Italy, Switzerland, Greece, Spain, and Portugal.

This suggests that policymakers are moving somewhat beyond the narrow interpretation of pension system sustainability adopted in previous decades. They realize there are potential feedback effects on overall fiscal outlays from the impact of reductions in pension system generosity and that if reforms leave a system unable to fulfill its goals, the possibility of policy reversals becomes quite probable. 


\section{Conclusion}

This paper aims to discuss the bi-path ways of risks in funded pension schemes. Here, we illuminate a hidden risk-shifting that was less studied, from the individual back to the government. This composition has stressed key dimensions of the complex public/private relationships and has drawn attention to aspects of risk-sharing between different periods and among different earning cohorts. In all of which the government plays a significant role as a central planner and as a mediator.

Consequently, financial torments strengthened the position of domestic opponents of pension privatization by highlighting private pension funds' disputed macroeconomic effects and volatile returns. After re-reforms of pension schemes in the last 15 years, more governments understand that the 1990s reforms were not coherent enough (Natali, 2018; Ebbinghaus, 2015). Over the last three decades, the experience in CEE and Latin American countries has demonstrated convergence to an equilibrium pension design. In those pension designs, the government recognizes its responsibilities in the risk-sharing framework and acts to diversify some of the traditional individual's risks. The recent financial crisis due to the COVID-19 pandemic confirms this process, as we witness large bailout governmental programs due to political pressure. The global public assistance to the pension market and labor markets emphasize the individual's inability to bear high fluctuations in the market for long, mainly during old age or when close to retirement. Policy analysis that focuses on a single objective, such as financial strength, will be flawed. One should understand that there is no single perfect design, and the solution depends mostly on the policy objectives and the underline economy.

This study's implication is the continuity of this trend of cyclical reforms in other countries that have based their pension systems on funded benefits, such as in the USA, Great Britain, Israel, or Iceland. The financial crisis will probably foster this breathing process as the public expects the government to participate in the risk. In this context, it is worthwhile to implement the above 'Risk-Sharing Orders Model' on the Notional Defined Contribution (NDC) pension scheme adopted by several countries, such as Poland, Latvia, and Kazakhstan (Bielawska, 2015). High poverty and inequality rates in these countries imply insufficient risk-sharing mechanisms (in Poland, benefit levels have not improved as the public pension continues to be based on a defined contribution system (NDC), which reduced the diversification effect and replacement rates remained low (39\% for men with 45 years of contributions and $34 \%$ for women with 40 years of contributions). In Kazakhstan, the implementation of NDC has merger replacement rates of $40 \%$ with 45 years of contribution. In Latvia, the old-age poverty rate is the highest among OECD countries after Korea.

The poverty rate is very volatile and highly connected to market fluctuations (OECD report on Latvia pension system. The pension scheme is expected to deliver replacement rates of $48 \%$ for an average worker with a full career (for comparison, the average in the OECD is 53\%, and Italy is $80 \%$ ) (Barr, 2006) that might cause 
another wave of pension re-reform in these countries. Compared to Norway, Sweden, and Italy, which implement the NDC scheme, there is a need for strong and mature markets and governance that is much more sophisticated and regulations to implement NDC schemes (Barr, 2006). Hence, perhaps implementing the NDC scheme in these countries is too early, where these countries are still undergoing a major structural transition toward the market economy. Additionally, as financial and systemic shocks are accelerating public reaction, it will be interesting to examine the pension systems design sometime after the Corona-Virus crisis.

\section{Reference}

Adams, W., Einav, L., Levin, J. 2009. Liquidity Constraints and Imperfect Information in Subprime Lending. American Economic Review, 99, 49-84. https://doi.org/10.1257/aer.99.1.49.

Altiparmakov, N. 2018. Another look at causes and consequences of pension privatization reform reversals in Eastern Europe. Journal of European Social Policy, 28(3), 224-241. https://doi.org/10.1177/0958928717735053.

Antolin, P., Payet, S., Whitehouse, E., Yermo, J. 2011. the role of guarantees in defined contributions pensions. The OECD library.

Arza, K. 2008. Pension reform in Latin America: Distributional principles, inequalities and alternative policy options. Journal of Latin American Studies, 40(1), 1-28. http://www.jstor.org/stable/40056624.

Barr, N. 2006. Non-financial defined contribution pensions: mapping the terrain. In Pension Reform of Holzmannm R. The World Bank. https://doi.org/10.1596/978-0-82136038-5.

Barr, N., Diamond, P. 2009. Reforming pensions: Principles, analytical errors and policy directions. International Social Security Review, 62(2), 5-29.

Bielawska, K. 2015. Pension reforms and long-term sustainability of public finances of the central eastern European countries. In: M. Szczepański, M. Szczepański (Ed), Social security systems in the light of demographic, economic and technological challenges: monograph, 21-32. Publishing House of Poznan University of Technology.

Bohn, H. 2010. Should Public Retirement Plans be Fully Funded? Cambridge.

Cristea, M., Thalassinos, I.E. 2016. Private Pension Plans: An Important Component of the Financial Market. International Journal of Economics and Business Administration 4 (1), 110-115, DOI: 10.35808/ijeba/95.

Einav, L. Finkelstein, A., Schrimpf, P. 2010. Optimal Mandates and the Welfare Cost of Asymetric Information: Evidence from the U.K. Annuity Market. Econometrica, 78(3).

Esping-andersen, g. 1990. Three worlds of welfare capitalism. Princeton, NJ: Princeton university press. (ed) In: Welfare states in transition: national adaptations in global economies. London: SAGE.

European Commission. 2010. Progress and Key Challenges in the Delivery of Adequate and Sustainable Pension in Europe. European Economy, 71. Brussels: DG Economic and Financial Affairs.

Fultz, E., Hirose, K. 2019. Second-pillar pensions in central and eastern Europe: Payment constraints and exit options. International Social Security Review, 72.

Goillier, C. 2008. Intergenerational risk sharing and risk taking of a pension fund. Journal of Public Economics, 92, 1463-1485. 
Grande, G., Visco, I. 2009. A public guarantee of a minimum return to defined contribution pension scheme members. Bank of Italy. Economic Research and International Relations Area, No 762.

Grech, A. 2018 What makes pension reforms sustainable. Sustainability, 10(8). https://doi.org/10.3390/su10082891.

Hardy, M. 2020. Diversification in retirement inequality, The Journals of Gerontology: Series B 75, 823-826. https://doi.org/10.1093/geronb/gbz147.

Holzmann, R, Hinz, R.P., Dorfman, M. 2008. Pension systems and reforms conceptual framework. Social Protection, Discussion Paper 0824.

Kuitto, K., Kuivalainen, S. 2020. Pension, in the Handbook on society and social policy, 279-290. https://doi.org/10.4337/9781788113526.00029.

Leisering, L. 2003. From redistribution to Regulation-Regulating private provisions for old-age as a new challenge for the welfare state in aging societies. Paper presented at the 4th International Research Conference on Social Security, Antwerp.

Mabbett, D. 2020. Reckless prudence: financialisation in UK pension scheme governance after the crisis. Review of International Political Economy. https://doi.org/10.1080/09692290.2020.1758187.

Markowitz, H. 2010. Portfolio theory as I still see it. Annual Review of Financial Economics, 2, 1-23. https://doi.org/10.1146/annurev-financial-011110-134602.

Marx, I. 2016. Raising minimum income floors: incrementalism and innovative pathways. Paper presented at the RC 19 Expansion and Retrenchment in Social Policy: North-South Dialogues Conference, San Jose.

Mesa Lago, C., Valero, D. 2020. The new wave of pension reforms in Latin America. In Peris-Ortiz M., Álvarez-García J., Domínguez-Fabián I., Devolder P. (eds), Economic challenges of pension systems. Springer, https://doi.org/10.1007/9783-030-37912-4_12.

Munnell, A., Quinby, L. 2009. Pension coverage and retirement security. Issues in Brief, ib2009-9-26, Center for Retirement Research.

Natali, D. 2008. Pensions in Europe, European pensions. Brussels: PIE Peter Lang.

Rappaport, A., Peterson, A. 2014. Risk-sharing alternatives for pension plan design: An overview and case studies. Wharton Pension Research Council Working Papers.

Reichling, F., Smetters, K. 2015. Optimal annuitization with stochastic mortality and correlated medical costs. American Economic Review, 105(11), 3273-3320. doi:10.1257/aer.20131584.

Republic of Bulgaria Report. 2017. Country fiche on pension projections. Sofia.

Tausch, F. et al. 2013. Preferences for redistribution and pensions. What can we learn from experience? Journal of Pension Economics and Finance, 12, 299.

Thalassinos, E., Cristea, M., Noja, G.G. 2019. Measuring active ageing within the European Union: implications on economic development. Equilibrium. Quarterly Journal of Economics and Economic Policy, 14(4), 591-609. https://doi.org/10.24136/eq.2019.028

Zaidi, A. 2010. Sustainability and adequacy of pension in EU countries: Synthesis from a cross-national perspective. European Papers on the New Welfare, 15, 65-76. 